\title{
PEMANFAATAN BUAH LOKAL SEBAGAI KOAGULAN SOY CHEESE
}

\author{
Risza Fawzia Rakhmah, Titik Suryani \\ Prodi Pendidikan Biologi FKIP Universitas Muhammadiyah Surakarta \\ Jl. Ahmad Yani Tromol Pos 1 Pabelan Kartasura Surakarta \\ E-mail korespondensi: suryanit@ymail.com
}

\begin{abstract}
Cheese is one of food product by coagulating process of milk protein. This experiment used the local fruit as soy milk coagulant of cheese made. The aim of the research was to know the effect of the local fruit as soy cheese coagulants on the protein content, organoleptic test and society accepted. The research method used complete random design (CRD) with two factors, the first factor were the various fruit (pineapple, lemon and citric acid as positive control) and the second factor were the concentrations of fruit (2\%; $3 \% 0,12 \%)$ by three replications. The result of this research showed that The highest protein of soy cheese was the addition of pineapple extract of $3 \%$, as $11,68 \mathrm{~g}$, while the lowest protein of soy cheese was the addition of lemon extract of $3 \%$ as $4,57 \mathrm{~g}$. The organoleptic test of soy cheese was most dominant, namely : soft texture, white-bone color, savory and slightly sour taste. The most dominant of society accepted was the treatment of lemon extract $3 \%$.
\end{abstract}

Keywords: soy cheese, pineapple extract, lemon extract, citric acid

\begin{abstract}
Abstrak - Keju merupakan salah satu produk pangan dengan proses penggumpalan protein susu. Penelitian ini memanfaatan buah lokal sebagai koagulan untuk menggumpalkan susu kedelai menjadi keju. Penelitian ini bertujuan untuk mengetahui pengaruh buah lokal sebagai koagulan pada soy cheese terhadap kadar protein, organoleptik dan daya terima masyarakat. Rancangan penelitian menggunakan Rancangan Acak Lengkap (RAL) 2 faktor 6 taraf perlakuan yaitu faktor 1: jenis buah (nanas, jeruk lemon dan asam sitrat (kontrol) dan konsentrasi $(0,12 \% ; 2 \% ; 3 \%$ ), masing-masing perlakuan dilakukan 3 ulangan. Metode penelitian yang digunakan adalah metode eksperimen, observasi, kepustakaan dan dokumentasi. Pengujian kadar protein menggunakan metode biuret, analisis data kadar protein menggunakan uji Two Way ANOVA dan dilanjutkan dengan uji Duncan's Multiple Range Test (DMRT), sedangkan pada pengujian organoleptik dan daya terima masyarakat menggunakan analisis deskriptif kualitatif berupa data angket. Hasil penelitian menunjukkan bahwa Kadar protein tertinggi soy cheese pada perlakuan ekstrak nanas $3 \%$ sebesar 11,68g, sedangkan kadar protein terendah soy cheese pada perlakuan ekstrak jeruk lemon $3 \%$ sebesar 4,57 g. keju paling dominan bertekstur lembut, warna putih tulang, rasa gurih dan sedikit asam. Daya terima panelis menyukai keju dengan penambahan ekstrak jeruk lemon $3 \%$. Penambahan ekstrak nanas dan jeruk lemon sebagai koagulan pada soy cheese berpengaruh terhadap kadar protein.
\end{abstract}

Kata kunci: soy cheese, ekstrak nanas, ekstrak jeruk lemon, asam sitrat 


\section{PENDAHULUAN}

Keju merupakan salah satu produk pangan yang berasal dari proses penggumpalan protein susu. Keju sudah tidak asing lagi dikalangan masyarakat Indonesia karena produk olahan susu ini dapat ditambahkan pada olahan makanan lainnya. Pada umumnya keju terbuat dari susu sapi.Namun kebutuhan susu yang meningkat mengakibatkan harga susu sapi makin mahal. Kandungan enzim laktose pada susu sapi yang biasa dikonsumsi dapat membuat alergi pada beberapa orang atau lactose intolerance (Brooker, 2005).Susu sapi dapat diganti dengan susu dari kacang-kacangan seperti susu kedelai yang berprotein tinggi sehingga dapat dikonsumsi oleh vegetarian dan harganya masih terjangkau.Kandungan gizi susu kedelai cair dan susu sapi tidak banyak berbeda . Kandungan protein susu kedelai lebih tinggi daripada susu sapi. Kedelai juga mengandung antioksidan berupa isoflavon yang berfungsi untuk menangkal radikal bebas (Winarsih, 2007).

Proses pengolahan susu menjadi keju dengan terbentuknya gumpalan (curd) keju yang dikoagulasi oleh enzim (Yulneriwarni, 2009). Enzim yang sering digunakan dalam penggumpalan curd yaitu enzim rennet yang diambil dari perut abdomen hewan memamah-biak (Nisa, 2009). Penggunaan enzim rennet dari perut abdomen hewan memamah-biak berdampak terhadap mahalnya harga susu yang akan dijadikan keju. Pada sisi kehalalan pembuatan keju sangat penting untuk masyarakat Indonesia yang mayoritas beragama islam.Rennet yang biasa digunakan untuk membuat homemade cheese di kalangan masyarakat modern yaitu dari kapang Rhizomucor miehei.Rennet komersil yang digunakan oleh masyarakat tersebut harus diimpor dari Australia sehingga biaya dan lama pengiriman menjadi hal utama dalam memilih rennet jenis ini.

Pembuatan keju dapat juga dilakukan dengan cara pengasaman langsung. Zat asam seperti ekstrak buah nanas (Ananas comosus) (Jaya, 2009) dan buah lemon (Citrus limon Burm.) (Wijayakusuma, 2008) dapat menghasilkan gumpalan pada susu. Selain itu, cara tersebut lebih terjangkau dan mudah untuk dipraktekkan.Nanas mengandung asam sitrat yang akan memberikan rasa manis dan asam pada buah.Kandungan fenolik pada buah nanas mampu meredam radikal bebas dalam tubuh (Adi, 2007).Buah lemon memiliki sifat kimia dan efek farmakologis seperti asam, sejuk, aromatik, berkhasiat antiscorbutic (mencegah sariawan), antioksidan, antibakterial, dan antiseptik. Buah lemon juga dapat menurunkan kadar kolesterol tinggi dan mengatasi radang tenggorokan (Wijayakusuma, 2007).

Hasil penelitian Sumarmono (2012:6667) bahwa kandungan protein keju dari bahan dasar susu sapi yang diasamkan dengan ekstrak nanas sebesar $47 \%$ dengan total padatan $54,14 \%$.

Hasil penelitian Razig (2009:1139) bahwa kandungan protein keju berbahan dasar susu sapi yang dilakukan dengan metode pengasaman langsung menggunakan ekstrak lemon sebesar 22,91\% dengan total padatan $53,32 \%$. Selain itu, hasil penelitian Harjono (2011:2) menunjukkan penambahan jus lemon berpengaruh nyata terhadap kadar protein pada keju $(\mathrm{P}<0,01)$ sebesar $25,11 \%$; $25,40 \% ; 25,66 \%$ dan $26,30 \%$ pada konsentrasi berturut-turut 1,75\%; $2,0 \% ; 2,25 \%$; dan $2,50 \%$.

Tujuan penelitian ini untuk mengetahui pengaruh buah lokal sebagai koagulan pada soy cheese terhadap kadar protein, sifat organoleptik dan daya terima masyarakat. 


\section{METODE PENELITIAN}

Penelitian ini dilaksanakan di Laboratorium Pangan Gizi Biologi dan pengujian kadar protein di Laboratorium Kimia Gizi FIK Universtas Muhammadiyah Surakarta. Metode yang digunakan pada penelitian ini yaitu metode eksperimen dengan menggunakan Rancangan Acak Lengkap (RAL) 2 faktor, yaitu jenis buah (nanas, jeruk lemon dan asam sitrat sebagai kontro positif ) dan konsentrasi ekstrak buah nanas dan jeruk lemon $(0,12 \% ; 2 \% ; 3$ $\%$ ),masing-masing perlakuan 3 ulangan.

Pelaksanaan penelitian diawali dengan pembuatan susu kedelai, kemudian dilanjutkan dengan pembuatan soy cheese. Pada pembuatan soy cheese, susu kedelai dipasteurisasi kemudian ditambahkan koagulan asam sitrat (kontrol positif ), ekstrak nanas (2\% dan $3 \%$ ), dan ekstrak lemon (2\% dan $3 \%$ )sampai terbentuk gumpalan (curd). Gumpalan yang terbentuk dipisahkan dengan whey dan ditambahkan garam dapur $(\mathrm{NaCl})$ $4 \% \mathrm{~b} / \mathrm{b}$. Analisis kadar protein soy cheese menggunakan metode biuret .Mengukur absorbansi pada panjang gelombang $520 \mathrm{~nm}$ kemudian memasukkan sampel dan mengujikan pada spektrofotometer. Pengujian organoleptik dilakukan oleh 20 panelis agak terlatih. Analisis data yang digunakan dalam penelitian ini menggunakan metode Two Way ANOVA dengan uji lanjut menggunakan metode Duncan's Multiple Range Test (DMRT) sedangkan analisis pengujian organoleptik dan daya terima masyarakat menggunakan metode deskriptif kualitatif.

\section{HASIL DAN PEMBAHASAN}

\section{Analisis Kadar Protein}

Berdasarkan Tabel 1 perlakuan $\mathrm{S}_{\mathrm{K}} \mathrm{K}_{0}$ dan $\mathrm{LK}_{2}$ memiliki notasi yang sama sehingga tidak ada pengaruh $(\mathrm{P}>0,01)$ penambahan buah lokal sebagai koagulan terhadap kadar protein pada soy cheese. Sedangkan pada perlakuan $\mathrm{NK}_{1}, \mathrm{NK}_{2}, \mathrm{~S}_{\mathrm{p}} \mathrm{K}_{0^{\prime}}$ dan $\mathrm{LK}_{1}$ ada pengaruh $(\mathrm{P}<0,01)$ penambahan buah lokal sebagai koagulan terhadap kadar protein pada soy cheese. Bahan koagulan dan banyaknya koagulan yang ditambahkan pada susu kedelai untuk membuat keju berpengaruh terhadap kadar protein yang dihasilkan.Perlakuan $\mathrm{NK}_{2}$ merupakan perlakuan yang terbaik, kadar protein soy cheese paling tinggi, yaitu 11,68 gram dan berada pada notasi " $\mathrm{e}$ ", pada perlakuan penambahan ekstrak nanas konsentrasi 3\%. 
Tabel 1.Hasil Rata-rata Kadar Protein Soy Cheese

\begin{tabular}{ccc}
\hline Sampel & Kadar protein $(\mathbf{g})$ & Keterangan \\
\hline $\mathrm{S}_{\mathrm{K}} \mathrm{K}_{0}$ & $4,69 \mathrm{a}$ & Susu kedelai + asam sitrat $0,12 \%$ \\
$\mathrm{~S}_{\mathrm{P}} \mathrm{K}_{0}$ & $7,02 \mathrm{bc}$ & Susu sapi + asam sitrat $0,12 \%$ \\
$\mathrm{NK}_{1}$ & $7,36 \mathrm{~cd}$ & Susu kedelai + ekstrak nanas $2 \%$ \\
$\mathrm{NK}_{2}$ & $11,68 \mathrm{e}$ & Susu kedelai + ekstrak nanas 3\% \\
$\mathrm{LK}_{1}$ & $5,34 \mathrm{ab}$ & Susu kedelai + ekstrak lemon $2 \%$ \\
$\mathrm{LK}_{2}$ & $4,57 \mathrm{a}$ & Susu kedelai +ekstrak lemon 3\% \\
\hline
\end{tabular}

Pada perlakuan $\mathrm{S}_{\mathrm{K}} \mathrm{K}_{0}$ dan $\mathrm{S}_{\mathrm{P}} \mathrm{K}_{0}$ diperoleh kadar protein keju dari susu sapi dan susu kedelai dengan penambahan asam sitrat $0,12 \%$ sebesar $4,69 \mathrm{~g}$ dan $7,02 \mathrm{~g}$. Perbedaan tersebut dapat terjadi pada saat working procees seperti pasteurisasi susu yang dapat mendenaturasi protein. Protein akan terdenaturasi pada saat pemanasan dan pengasaman.

Pada perlakuan $\mathrm{NK}_{1}$ dan $\mathrm{NK}_{2}$ diperoleh hasil kadar protein soy cheese dengan ekstrak nanas $2 \%$ dan 3\% berturut turut 7,36g dan 11,68 g. Peningkatan kadar protein pada keju dengan konsentrasi ekstrak nanas yang lebih tinggi selain karena mengandung asam yang dapat membantu menggumpalkan protein, nanas juga mengandung enzim bromelin. Enzim bromelin merupakan enzim protease dalam buah nanas yang dapat membantu menghidrolisis protein menjadi asam amino. Hasil penelitian Khotijah (2011) bahwa semakin lama perendaman kacang merah dalam sari kulit nanas dapat meningkatkan kadar protein tempe kacang merah. Hasil penelitian Marminah (2012) bahwa terdapat perbedaan kadar protein $(\mathrm{P}<0,01)$ antara tape singkong tanpa sari buah nanas dengan tape singkong yang ditambahkan sari buah nanas. Hal ini menyebabkan tape singkong yang ditambahkan sari buah nanas memliki kadar protein yang lebih tinggi dibandingkan dengan tape singkong tanpa penambahan sari buah nanas.

Pada perlakuan $\mathrm{LK}_{1}$ dan $\mathrm{LK}_{2}$ diperoleh hasil kadar protein soy cheese dengan ekstrak jeruk lemon 2\% dan 3\% berturut-turut sebesar 5,34g dan 4,57 g. Hasil penelitian ini berbeda dengan hasil penelitian Harjono (2011) bahwa penambahan jus lemon berpengaruh nyata terhadap kadar protein padakeju1,75\%; 2,0\%; 2,25\%; dan 2,50\%. Menurut Purwadi (2010) penggunaan asam yang kurang atau berlebih menyebabkan curd yang dihasilkan lembekdan. rapuh serta kasein hilang bersama whey. Metzger et al. (2001) menyimpulkan penelitiannya bahwa pengasaman awal dapat mempengaruhi kadar protein keju $(\mathrm{P}<0,01)$ sebesar $25,11 \%$; $25,40 \% ; 25,66 \%$ 


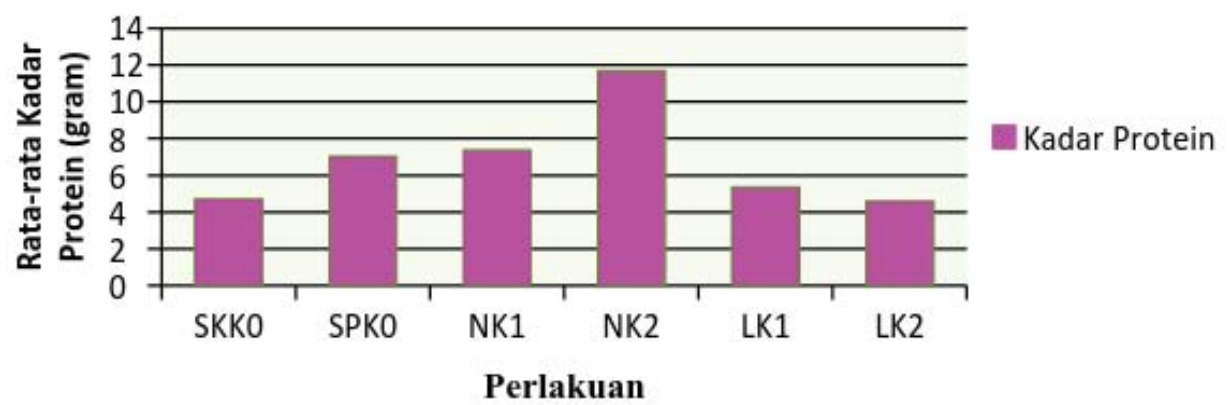

Gambar 1. Histogram Rata-Rata Hasil Uji Kadar Protein Soy Cheese dengan Penambahan Koagulan nanas dan jeruk lemon

\section{Analisis Organoleptik dan Daya Terima}

\section{Masyarakat}

Tabel 2.Hasil Uji Organoleptik dan Daya Terima Masyarakat pada Soy Cheese

\begin{tabular}{|c|c|c|c|c|c|}
\hline \multirow{2}{*}{ Perlakuan } & \multicolumn{4}{|c|}{ Uji Organoleptik } & \multirow{2}{*}{$\begin{array}{l}\text { Daya } \\
\text { Terima }\end{array}$} \\
\hline & Tekstur & Aroma & Rasa & Warna & \\
\hline $\mathrm{S}_{\mathrm{K}} \mathrm{K}_{0}$ & Agak kasar & Harum kedelai & $\begin{array}{c}\text { Gurih dan } \\
\text { sedikit asam }\end{array}$ & Putih tulang & $\begin{array}{l}\text { Agak } \\
\text { suka }\end{array}$ \\
\hline $\mathrm{S}_{\mathrm{P}} \mathrm{K}_{0}$ & Lembut & Harum susu sapi & $\begin{array}{c}\text { Asin dan agak } \\
\text { asam }\end{array}$ & Putih & $\begin{array}{l}\text { Agak } \\
\text { suka }\end{array}$ \\
\hline $\mathrm{NK}_{1}$ & Lembut & $\begin{array}{l}\text { Harum kedelai } \\
\text { dan nanas }\end{array}$ & $\begin{array}{l}\text { Gurih dan } \\
\text { sedikit asam }\end{array}$ & Putih tulang & $\begin{array}{l}\text { Agak } \\
\text { suka }\end{array}$ \\
\hline $\mathrm{NK}_{2}$ & Lembut & $\begin{array}{l}\text { Harum kedelai } \\
\text { dan nanas }\end{array}$ & $\begin{array}{c}\text { Gurih dan } \\
\text { sedikit asam }\end{array}$ & Kekuningan & $\begin{array}{l}\text { Agak } \\
\text { suka }\end{array}$ \\
\hline $\mathrm{LK}_{1}$ & Lembut & $\begin{array}{l}\text { Harum lemon } \\
\text { dan sedikit } \\
\text { harum kedelai }\end{array}$ & $\begin{array}{l}\text { Gurih dan } \\
\text { sedikt asam }\end{array}$ & Putih tulang & $\begin{array}{l}\text { Agak } \\
\text { suka }\end{array}$ \\
\hline $\mathrm{LK}_{2}$ & Lembut & $\begin{array}{c}\text { Harum lemon } \\
\text { dan sedikit } \\
\text { harum kedelai }\end{array}$ & $\begin{array}{l}\text { Gurih dan } \\
\text { sedikit asam }\end{array}$ & Putih tulang & $\begin{array}{l}\text { Agak } \\
\text { suka }\end{array}$ \\
\hline
\end{tabular}

a. Tekstur

Dari Tabel 2 menunjukkan bahwa tekstur keju pada perlakuan $\mathrm{S}_{\mathrm{K}} \mathrm{K}_{0}$ agak kasar; sedangkan perlakuan $\mathrm{S}_{\mathrm{P}} \mathrm{K}_{0^{\prime}}$ $\mathrm{NK}_{1}, \mathrm{NK}_{2}, \mathrm{LK}_{1}$, dan $\mathrm{LK}_{2}$ lembut. Tekstur keju dipengaruhi oleh kadar air. Air merupakan komponen penting dalam bahan pangan karena air dapat mempengaruhi kekerasan, penampakan, citarasa dan nilai gizinya (Putri, 2007).

b. Aroma

Hasil uji organoleptik (dari panelis ) menunjukkan bahwa aroma pada perlakuan $\mathrm{S}_{\mathrm{K}} \mathrm{K}_{0}$ harum kedelai.Hal ini disebabkan oleh 
penambahan koagulan asam sitrat. Penambahan asam sitrat digunakan sebagai pencegah rusaknya aroma (Kusumawati, 2008) sehingga aroma kedelai sangat terasa pada perlakuan tersebut. Pada perlakuan $\mathrm{S}_{\mathrm{P}} \mathrm{K}_{0}$ memiliki aroma harum susu sapi, aroma ini berasal dari bahan utama keju (susu sapi) pada perlakuan $\mathrm{LK}_{1}$ dan $\mathrm{LK}_{2}$ harum kedelai dan nanas. Sedangkan pada perlakuan $\mathrm{LK}_{1}$ dan $\mathrm{LK}_{2}$ harum lemon dan sedikit harum kedelai.Harum lemon ini dikarenakan lemon mengandung limonin.Limonin adalah jenis komponen kimia dalam minyak atsiri berupa terpen, senyawa ini memiliki wangi dan aroma khas lemon (Arifin, 2006).

c. Rasa

Rasa dapat dinilai karena adanya tanggapan rangsangan kimiawi oleh indera pencicip (lidah) yang meliputi kesatuan interaksi antara sifatsifat aroma dan tekstur serta dapat mempengaruhi penilaian konsumen terhadap suatu produk (Martini, 2002). Hasil uji organoleptik pada 20 panelis menunjukkan bahwa pada semua perlakuan, panelis memilih gurih dan sedikit asam. Penambahan asam sitrat, ekstrak nanas dan lemon digunakan sebagai pemberi rasa asam pada makanan (Kusumawati, 2008) sedangkan rasa gurih diperoleh dari penambahan garam dapur pada masing-masing perlakuan. Rasa dipengaruhi oleh senyawa kimia, suhu, konsentrasi dan interaksi dengan komponen rasa yang lain (Putri, 2007). d. Warna

Penentuan mutu bahan makanan pada umumnya sangat bergantung pada beberapa faktor diantaranya adalah warna, rasa, dan nilai gizinya.Selain beberapa faktor yang ikut menentukan mutu, warna juga dapat digunakan sebagai indikator kematangan suatu produk pangan (Rachmawati, 2012). Hasil uji organoleptik dari 20 panelis menunjukkan bahwa pada perlakuan $\mathrm{S}_{\mathrm{K}} \mathrm{K}_{0^{\prime}} \mathrm{NK}_{1}, \mathrm{LK}_{1}$ dan $\mathrm{LK}_{2}$ keju berwarna putih tulang, $\mathrm{NK}_{2}$ berwarna kekuningan; sedangkan $\mathrm{S}_{\mathrm{P}} \mathrm{K}_{0}$ berwarna putih. Kecerahan warna dipengaruhi oleh lemak susu yang melarutkan pigmen karoten penyebab warna kuning dan pigmen laktoflavin atau laktokrom yang larut dalam air. Adanya zat warna atau vitamin yang larut dalam lemak akan memberikan warna kekuningan pada koagulum yang terbentuk (Jaya, 2009).

e. Daya Terima Masyarakat

Daya terima masyarakat atau dapat disebut parameter overall (keseluruhan) merupakan parameter penerimaan umum yang dilakukan untuk mengetahui penerimaan konsumen secara menyeluruh terhadap suatu produk (Martini, 2009). Hasil uji organoleptik menunjukkan bahwa daya terima panelis yang paling dominan pada semua perlakuan keju yaitu agak suka. Daya terima masyarakat dipengaruhi oleh uji organoleptik yang telah dilakukan sebelumnya dan tingkat kesukaan panelis yang berbeda. 
Namun, berdasarkan Gambar 4.3 bahwa pada perlakuan $\mathrm{LK}_{2}$ memiliki range rata-rata paling tinggi. Hal ini disebabkan oleh aroma lemon pada perlakuan $\mathrm{LK}_{2}$ sangat disukai panelis. Sedangkan range rata-rata terendah pada perlakuan $\mathrm{LK}_{1}$, karena aroma lemon yang dihasilkan kurang tajam sehingga panelis hanya memilih kriteria agak suka pada keju atau soy cheese.

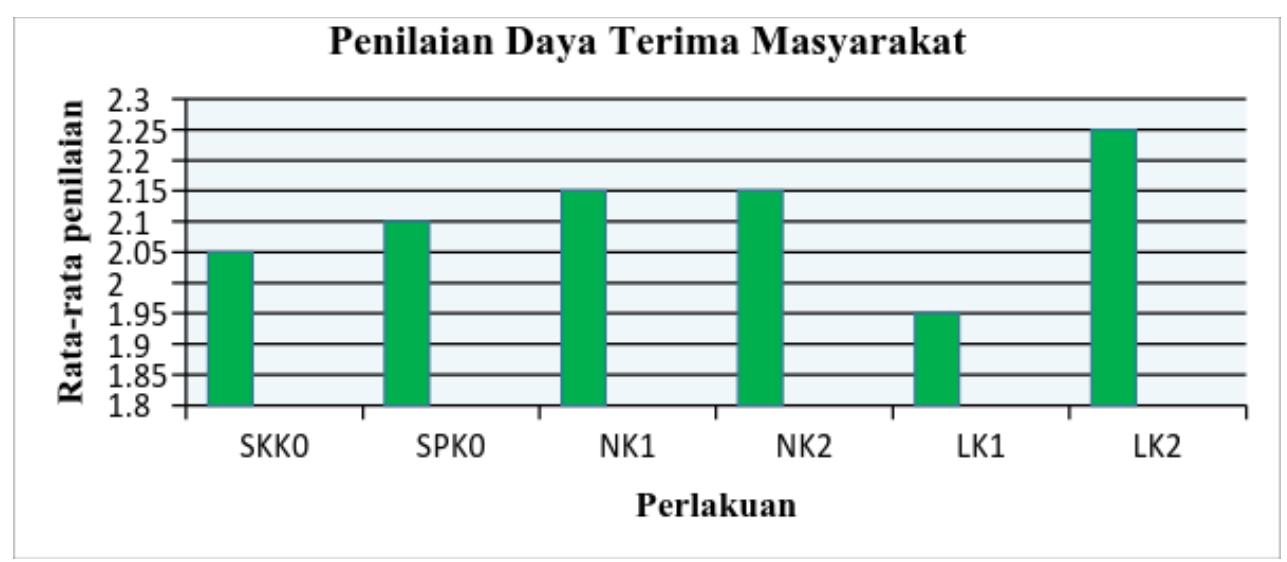

Gambar 2. Histogram Penilaian Daya Terima Masyarakat pada Soy Cheese

\section{KESIMPULAN}

Kadar protein tertinggi soy cheese pada perlakuan ekstrak nanas 3\% sebesar 11,68g, sedangkan kadar protein terendah soy cheese pada perlakuan ekstrak jeruk lemon $3 \%$ sebesar $4,57 \mathrm{~g}$. keju paling dominan bertekstur lembut, warna putih tulang, rasa gurih dan sedikit asam. Daya terima panelis menyukai keju dengan penambahan ekstrak jeruk lemon $3 \%$. Penambahan ekstrak nanas dan jeruk lemon sebagai koagulan pada soy cheese berpengaruh terhadap kadar protein.

\section{DAFTAR PUSTAKA}

Adi, Lukas Tersono. 2007. Sehat Berdasarkan Golongan Darah. Jakarta : Agromedia, hal. 111

Arifin, Zainul. 2006. Kajian Proses Pembuatan Serbuk Kulit Jeruk lemon (Citrus medica var Lemon) sebagai Flavor Teh Celup. Skripsi.Bogor : Fakultas Teknolog Pertanian, IPB, hal. 16
Brooker, Chris. 2005. Ensiklopedia Keperawatan. Terjemahan oleh Andry Hartono, Brahm U. Pendit, dan Widiarti. 2009. Jakarta : EGC, hal. 365

Harjono, Fondha Teguh Eko. 2011. Penggunaan Jus Buah Jeruk Lemon (Citrus lemon) pada Pembuatan Keju Mozarella. Abstract. UNIBRAW, hal. 2

Jaya, Firman dan Didik Hadikusuma. 2009. Pengaruh Substitusi Susu Sapi dengan Susu Kedelai serta Besarnya Konsentrasi Penambahan Ekstrak Nenas (Ananas comosus) terhadap Kualitas Fisik dan Kimia Keju Cottage. U : Universitas Tribhuwana Tunggadewi, hal. 4652

Khotijah.2011. Pengaruh Perendaman Kacang Merah dalam Sari Kulit 
Nanas Terhadap Kadar Protein dan Kualitas Tempe Kacang Merah. Skripsi.Surakarta : Program Studi Pendidikan Biologi, FKIP UMS, hal. 37

Kusumawati, Riska Pratama. 2008. Pengaruh Penambahan Asam Sitrat dan Pewarna Alami Kayu Secang (Caesalpinia sappan L) Terhadap Stabilitas Warna Sari Buah Belimbing Manis (Averrhoa carambola L.).Skripsi.Bogor : Fakultas Teknologi Pertanian, Institut Pertanian Bogor, hal. 13-23

Marminah. 2012. Perbedaan kadar Protein Tape Singkong (Manihot utilisima) Biasa dengan yang Diberi Penambahan Sari Buah Nanas (Ananas comosus). Skripsi.Surakarta : Program Studi Pendidikan Biologi, FKIP UMS, hal. 30

Martini, Titi. 2002. Kajian Pembuatan Tepung Cake Tape Ubi Kayu (Manihot esculenta Crantz) Instan Dan Penerimaan Konsumen Terhadap Mutu Organoleptik Cake. Skripsi. Bogor : Fakultas Teknologi Pertanian, Institut Pertanian Bogor, hal. 40

Metzger, LE, Barbano DM, Kindstedt PS, and Guo MR. 2001.Effect of Milk Preacidification on Low Fat Mozarella Cheese : II. Chemical and Functional Properties During Storange. Journal Dairy Science. Jun;84(6): 1348-56. New York : Cornell University

Nisa, Chairun, Trioso Purnawarman, Ita Djuwita, dan Chusnul Choliq. 2009. Produksi dan Uji Biologis Rennet dari Abomasum Domba Lokal sebagai Bahan Bioaktif dalam Pembuatan Keju. Bogor : Fakultas Kedokteran Hewan IPB, hal. 1
Purwadi.2010. Kualitas Fisik Keju Mozarella dengan Bahan Pengasam Jus Jeruk Nipis.Jurnal Ilmu dan Teknologi Hasil Ternak.Kediri : Fakultas Peternakan, Universitas Brawijaya, hal. 36

Putri, Yeny Nur. 2007. Mempelajar Pengaruh Penyimpanan Tape Ketan (Oryza sativa glutinosa)Terhadap Daya Terima Konsumen. Skripsi.Bogor :Departemen Ilmu dan Teknologi Pangan, Fakultas Teknologi Pertanian IPB, hal. 29-51

Rachmawati, Ulfiah. 2012. Pemanfaatan Susu Sapi dalam Pembuatan Keju Tradisional dengan Penambahan Ekstrak Jeruk Manis (Citrus sinensis Osbeck) dan Jambu Biji (Psidium guajava). Skripsi.Surakarta : Jurusan Biologi FKIP UMS, hal. 36

Razig, Kamal Awad Abdel dan Nagla Ali Ahmad Babiker. 2009. Chemical and Microbiological Properties od Sudanese White Soft Cheese Made by Direct Acidification Technique. Journal of Nutrition.Sudan : AlZalem Al-Azhari University, page 1139

Sumarmono, J dan F.M. Suhartati. 2012. Yield dan Komposisi Keju Lunak (Soft Cheese) dari Susu Sapi yang dibuat Dengan Teknik Direct Acidification menggunakan Ekstrak Buah Lokal. Jurnal Aplikasi Teknologi Pangan. Hal. 66-67

Wijayakusuma, Hembing. 2008. Ramuan Herbal Penurun Kolesterol.Jakarta : Pustaka Bunda, hal. 57

Winarsi, Hery. 2007. Antioksidan Alami dan Radikal Bebas:Potensi dan Aplikasinya dalam Kesehatan. Yogyakarta : Kanisius, hal. 183 
Yulneriwarni, Sulastri, dan Lydia Tuti. 2009. Fermentasi Keju dari Berbagai Jenis Kacang Menggunakan Isolat Bakteri
Asam Laktat dari Nenas.Jakarta : Fakultas Biologi, Universitas Nasional, hal 32 